\title{
The "FIFA 11+" warm-up programme for preventing injuries in soccer players: a systematic review
}

\section{Programa de aquecimento FIFA "The 11 +" para prevenção de lesões em jogadores de futebol: uma revisão sistemática}

\author{
Alex de Andrade Fernandes ${ }^{[a]}$, Cristiano Diniz da Silva ${ }^{[b]}$, Israel Teoldo da Costa ${ }^{[c]}$, \\ João Carlos Bouzas Marinss ${ }^{[\mathrm{c}] *}$ \\ [a] Instituto Federal de Educação, Ciência e Tecnologia de Minas Gerais (IFMG), Bambuí, MG, Brazil \\ ${ }^{[b]}$ Universidade Federal de Juiz de Fora (UFJF), Governador Valadares, MG, Brazil \\ ${ }^{[c]}$ Universidade Federal de Viçosa (UFV), Viçosa, MG, Brazil
}

\begin{abstract}
Introduction: Soccer is among the sports with the highest injury rate. A group of international experts from the Fédération Internationale de Football Association — FIFA's Medical Assessment and Research Centre - have developed the "FIFA 11+", a warm-up programme whose main goal is to reduce the risk of common injuries in both male and female soccer players. Objective: To conduct a literature review in order to check the efficiency of the "FIFA $11+$ " warm-up programme in preventing injuries in soccer players. Methods: We conducted a systematic review of studies in the databases MEDLINE/PubMed, SciELO, ScienceDirect and SPORTDiscus,
\end{abstract}

* AAF: MSc, e-mail: alex.andrade@ifmg.edu.br CDS: MSc, e-mail: cristianodiniz.silva@gmail.com ITC: PhD, e-mail: israelteoldo@gmail.com JCBM: PhD, e-mail: jcbouzas@ufv.br 
using the following keywords in combination with one another: "injury", "prevention" and "warm-up". Results: Five studies met the inclusion criteria. In 4 studies, the authors conclude that the "FIFA 11 +" warm-up programme is effective for preventing injuries in soccer players. In 1 study, this protective effect was not observed. Conclusion: The analyzed studies indicate that the FIFA 11+ warm-up programme for the prevention of sports injuries show positive signs that the use of the programme may help reduce the incidence of injuries in girls aged 13-17 years. In a male children population the results are inconclusive and further research is needed.

Keywords: Soccer. Athletes. Athletic injuries. Exercise movement techniques.

\section{Resumo}

Introdução: O futebol está entre os esportes com maior incidência de lesão quando comparado a outras modalidades esportivas. Um grupo de especialistas internacionais da Fédération Internationale de Football Association - FIFA's Medical Assessment and Research Centre - desenvolveram o "The 11+", um programa de aquecimento que possui como principal objetivo reduzir o risco de lesões mais comuns de jogadores de futebol de ambos os sexos. Objetivo: Verificar, por meio de revisão de literatura, a eficácia do programa de aquecimento "The 11+" para prevenir lesões em atletas de futebol. Método: Realizou-se uma revisão sistemática da literatura, utilizando as palavras-chave "Injury", "prevention" e "warm-up", em cruzamento, nas bases de dados MEDLINE/PubMed, SciELO, ScienceDirect e SPORTDiscus. Resultados: Foram selecionados após processo de filtragem 5 estudos que atenderam aos critérios de inclusão e exclusão, em 4 estudos os autores concluem que o programa de aquecimento "The 11+" é eficiente para prevenir lesões em atletas de futebol e em 1 estudo não observou-se o efeito protetor. Conclusão: Tendo em vista os estudos analisados, o programa de aquecimento voltado para prevenção de lesões esportivas "The 11+" apresenta indícios positivos de que pode reduzir a taxa de incidência de lesões em meninas na faixa etária de 13 a 17 anos. Em uma população de meninos os resultados não são conclusivos, sendo necessários mais estudos.

Palavras-chave: Futebol. Atletas. Lesões em atletas. Técnicas de exercício e de movimento.

\section{Introduction}

According to the Fédération Internationale de Football Association (FIFA), football/soccer can be considered the most popular sport in the world (1). The latest worldwide survey, conducted in 2006, estimated approximately 265 million men and women, over the age of 18, who were soccer players (2). Although engagement in soccer activities leads to significant physical benefits such as improvement in well-being (3), increased life expectancy and reduced likelihood of contracting several major noncommunicable diseases (4), the risk of incurring injuries from soccer must be considered.

Given that soccer is among the sports with the highest injury rate $(5,6,7,8,9)$, soccer players are at substantial risk for developing injuries $(1,10,11)$. On average an elite soccer player suffers 1.5 to 7.6 injuries per thousand hours of training and 12-35 injuries per thousand hours of match play $(12,13)$. The head, the muscles of the thighs and calves, the knees, the lower leg, ankle and foot are the body-parts most susceptible to injuries during soccer training or match play (12-15). Therefore, new insights for the prevention of soccer injuries benefit not only professional soccer players and their clubs, but also all those people who see this sport as a means of recreation and fitness.

Thus, a variety of exercise programmes have been developed with the aim of reducing the number of injuries resulting from soccer practice (16-19). These exercise programmes may be performed as part of the athletes' warm-up, as in other sport disciplines, which might reduce the validity of such a routine. In this sense, more specific exercises need to be added to the warm-up routine. These exercises need to respect the physical demands of soccer, aiming to be a means of improving static and dynamic balance, 
neuromuscular control and proprioception, especially of the knee and hip.

In order to meet this need, a group of international experts from the following groups: FIFA's Medical Assessment and Research Centre (F-MARC), Oslo Sports Trauma Research Center, Santa Monica Orthopaedic and Sports Medicine Research Foundation - who had previous experience in soccer injury prevention programmes - developed a specific program to prevent injuries in soccer: the FIFA $11+$. This programme is developed in three stages and has a total of 15 exercises. A very specific sequence needs to be followed and the programme must be performed before each training session. The first stage consists of running exercises with low displacement speed (i.e., trotting and slow running 8-10 km.h $\left.{ }^{-1}\right)$, combined with active stretching temporarily (20-30 s) controlled together with colleagues. The second stage consists of six exercises (with three levels of difficulty each) to the muscle groups of the legs and focus on balance, strength, agility and on plyometric exercises (i.e., involving high-speed stretch-shortening cycle exercises, such as jumping and acceleration-deceleration). The third stage consists of running exercises at moderate and high speed, combined with change of direction (20).

According to the developers of the "The 11+", it can be considered as a complete warm-up programme whose main goal is to reduce the risk of common injuries that are associated with soccer (20). Among the advantages of "The 11+" are the fact that the programme takes about 15-20 minutes to complete - depending on the athletes' experience with the exercises - and requires no equipment other than a soccer ball. Another considerable advantage is that the programme is described in detail on a DVD and other materials to enhance the understanding of the exercises, such as a technical manual, videos, posters and cards, can be accessed freely through the FIFA website (http://f-marc.com/11plus/). It is important to highlight that these exercises are not new, but they have not yet become routine in training programs. The new aspect is that these exercises are brought together in a programme that is simple and viable, and could be a standard warm-up before training sessions.

In this sense, different studies $(10,16,21,23)$ have been conducted with the aim of assessing the effectiveness of the FIFA 11+ warm-up programme in reducing the number of injuries sustained by soccer players. Previous evidence indicates over $40 \%$ reduction in the risk of injury (16). However, several factors may be associated with the risk of injury during soccer (i.e., competitive level, age, gender). In addition, these injuries may affect different parts of the body and be caused by different mechanisms of injury, such as traumatic or overuse $(14,15)$.

The objective of this study was to conduct a systematic review of studies specifically investigating the efficiency of the FIFA 11+ warm-up programme in preventing injuries in soccer players.

\section{Methods}

From January through March 2014, an electronic search was conducted in the following databases: MEDLINE/PubMed, SciELO, ScienceDirect and SPORTDiscus. The search period was set from January 2005 (year of publication of the FIFA 11+ programme) to March 2014. We used the following keywords in combination with one another: injury, prevention, warm-up, soccer and The 11t.

The process of search and selection of studies was performed by two researchers independently, according to the inclusion and exclusion criteria defined in the study protocol, which were: (I) population (soccer players), (II) intervention (completion of the FIFA $11+$ warm-up programme with no adjustments during the training period), (III) outcome (reduction or not in the number of injuries). We assessed the titles and abstracts of all retrieved references, and obtained the full articles for any references whose titles and abstracts were not specific enough.

\section{Results}

Using the keywords injury, prevention, warm-up, soccer and FIFA 11+ in combination with one another, we found 213 articles. Of these, 208 articles were excluded because they did not meet the inclusion criteria. Thus, this review was composed of 5 studies/ articles (Figure 1). Table 1 shows a summary of the articles and their results, based on selected reports. In this review, we present the author of the article, the gender and the number of study participants, the exercise protocol and the main results of the study. 


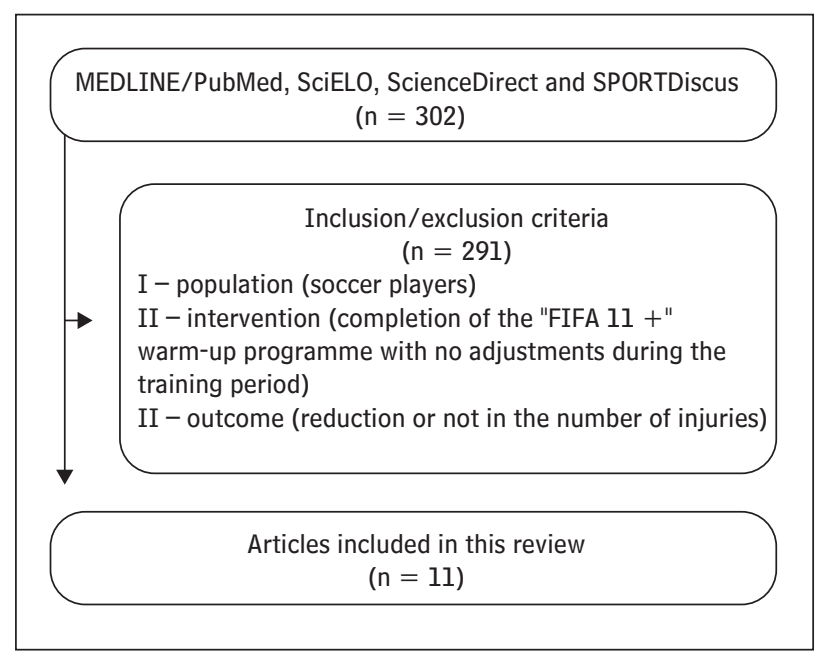

Figure 1 - Flowchart of the articles selection process

\section{Discussion}

The objective of this study was to conduct a systematic review of studies specifically investigating the efficiency of the FIFA 11+ warm-up programme in preventing injuries in soccer players. In 10 of the 11 studies presented in this systematic review, the authors conclude that the warm-up programme FIFA $11+$ is effective in preventing injuries in soccer players. Thus, this article summarizes 10 years of scientific and field work regarding the prevention of injuries with the FIFA $11+$ programme. This makes possible to formulate actions in order to make the soccer safer, especially with regard to the prevention of injuries at amateur level.

Table 1 - Summaries of the articles and their results based on reports about the possible effects of FIFA $11+$ warm-up programme

(To be continued)

\begin{tabular}{|c|c|c|c|c|c|}
\hline Author & $\mathbf{G}$ & $\mathbf{N}$ & Age & Study characteristics & Main results \\
\hline $\begin{array}{l}\text { Steffen et al. } \\
(23)\end{array}$ & $\mathrm{F}$ & 2020 & $\begin{array}{l}\text { Average } \\
15.4 \pm \\
0.8\end{array}$ & $\begin{array}{l}1073 \text { athletes in the intervention group and } \\
947 \text { athletes in the control group. Intervention } \\
\text { implemented from April to October } 2005 .\end{array}$ & $\begin{array}{l}\text { There was no statistically significant difference } \\
\text { between the injury rate of the intervention } \\
\text { group }(3.6 / 1000 \mathrm{~h}) \text { and the control group } \\
(3.7 / 1000 \mathrm{~h}) \text {. }\end{array}$ \\
\hline $\begin{array}{l}\text { Soligard et al. } \\
(10)\end{array}$ & $\mathrm{F}$ & 1892 & $13-17$ & $\begin{array}{l}1055 \text { athletes in the intervention group and } \\
837 \text { athletes in the control group. Intervention } \\
\text { implemented from March to October } 2007 .\end{array}$ & $\begin{array}{l}264 \text { players suffered injuries: } 121 \text { players in } \\
\text { the intervention group and } 143 \text { players in the } \\
\text { control group, during one season } \\
\text { ( } 8 \text { months). }\end{array}$ \\
\hline $\begin{array}{l}\text { Junge et al. } \\
\text { (21) }\end{array}$ & ND & ND & ND & $\begin{array}{l}\text { In } 2005,5549 \text { amateur team coaches from } \\
\text { the Swiss Football Federation (FSF) received } \\
\text { information materials and training, and were } \\
\text { requested to implement the FIFA } 11+\text { in the } \\
\text { training routine. }\end{array}$ & $\begin{array}{l}\text { In } 2008 \text {,the programme was constantly } \\
\text { carried out by } 57 \% \text { of the coaches. Those } \\
\text { teams who performed the programme had } \\
\text { an incidence of injury } 11.5 \% \text { lower during } \\
\text { matches and } 25.3 \% \text { lower during training, } \\
\text { when compared with teams that did not } \\
\text { perform the programme. On average, the } \\
\text { teams would train twice a week and play one } \\
\text { match per week. }\end{array}$ \\
\hline $\begin{array}{l}\text { Soligard et al. } \\
(16)\end{array}$ & $\mathrm{F}$ & 1892 & $13-17$ & $\begin{array}{l}\text { Intervention implemented from March to } \\
\text { October } 2007.837 \text { athletes in the control } \\
\text { group and } 1055 \text { athletes in the intervention } \\
\text { group. }\end{array}$ & $\begin{array}{l}\text { The risk of injury dropped } 35 \% \text { when } \\
\text { comparing those athletes who performed } \\
\text { on average } 1.5 \text { sessions of the programme } \\
\text { FIFA } 11+\text { per week and those athletes who } \\
\text { performed } 0.7 \text { sessions per week. }\end{array}$ \\
\hline $\begin{array}{l}\text { Beijsterveldt } \\
\text { et al. (24) }\end{array}$ & $M$ & ND & $18-40$ & $\begin{array}{l}\text { Control group composed of } 155 \text { athletes from } \\
12 \text { clubs and intervention group composed of } \\
155 \text { athletes from } 12 \text { clubs. The "FIFA } 11+\text { " } \\
\text { programme was performed } 2 \text { to } 3 \text { times a } \\
\text { week during an entire season. }\end{array}$ & $\begin{array}{l}\text { During training and matches the incidence of } \\
\text { injuries and their severity were lower in the } \\
\text { intervention group, as well as the costs of } \\
\text { treatment in athletes who suffered injuries. }\end{array}$ \\
\hline
\end{tabular}


Table 1 - Summaries of the articles and their results based on reports about the possible effects of FIFA $11+$ warm-up programme

(Conclusion)

\begin{tabular}{|c|c|c|c|c|c|}
\hline Author & G & N & Age & Study characteristics & Main results \\
\hline $\begin{array}{l}\text { Gatterer et al. } \\
\text { (25) }\end{array}$ & M & ND & ND & $\begin{array}{l}\text { Three amateur soccer teams, two in the } 6^{\text {th }} \\
\text { Italian division, were divided into a control } \\
\text { and an intervention group to perform the } \\
\text { FIFA } 11+\text {, programme. Another team was in } \\
\text { the } 7^{\text {th }} \text { division. During the first round of the } \\
\text { national competition. }\end{array}$ & $\begin{array}{l}\text { The total injury rate for intervention in the control } \\
\text { team in the 6th division was } 3.3 \text { injuries/ } 1000 \mathrm{~h} \\
(\mathrm{Cl} 0.7-5.9 \text { ) and } 4.3 \text { injuries } / 1000 \mathrm{~h} \text { (IC } \\
1.3-7.3) \text {, respectively. Relative risk was } 2 \text { times } \\
\text { higher in the } 7^{\text {th }} \text { division club when compared } \\
\text { with } 6^{\text {th }} \text { division team. }\end{array}$ \\
\hline $\begin{array}{l}\text { Grooms et al. } \\
\text { (26) }\end{array}$ & $M$ & 41 & $18-25$ & $\begin{array}{l}\text { A high-school soccer team was followed- } \\
\text { up for } 2 \text { seasons. The first season was } \\
\text { considered control and the second was an } \\
\text { intervention season, with performance of the } \\
\text { FIFA 11+ programme. }\end{array}$ & $\begin{array}{l}\text { The intervention season had reductions in the } \\
\text { relative risk (RR) of lower extremity injury of } \\
72 \%(\mathrm{RR}=0.28, \mathrm{Cl} 95 \%=0.09,0.85)\end{array}$ \\
\hline $\begin{array}{l}\text { Steffen et al. } \\
\text { (27) }\end{array}$ & $\mathrm{F}$ & 226 & $13-18$ & $\begin{array}{l}\text { The control group was composed of } 80 \\
\text { athletes whose coaches did not follow the } \\
\text { FIFA11+ programme. The intervention } \\
\text { group (I) was composed of } 68 \text { athletes. } \\
\text { The coaches in this group were previously } \\
\text { trained on how to carry out the FIFA } 11+ \\
\text { programme. The coaches of the intervention } \\
\text { group (II) were trained on how to perform the } \\
\text { FIFA } 11+\text { programme and the group was also } \\
\text { followed-up by a physical therapist. During } \\
\text { the } 2011 \text { season (May-August). }\end{array}$ & $\begin{array}{l}\text { The risk of injury was lower among those } \\
\text { players who showed high adherence to the } \\
\text { FIFA11+ programme, intervention group (II). }\end{array}$ \\
\hline $\begin{array}{l}\text { Daneshjoo et } \\
\text { al. (28) }\end{array}$ & M & 36 & $17-19$ & $\begin{array}{l}\text { Players were divided into } 3 \text { groups: FIFA } \\
11+, \text { HarmoKnee and control ( } n=12 \text { in } \\
\text { each group). These exercises were performed } \\
3 \text { times a week for } 2 \text { months ( } 24 \text { sessions). } \\
\text { The study assessed ratios associated with } \\
\text { the risk of knee injuries in soccer players } \\
\text { (conventional strength ratio [CSR], dynamic } \\
\text { control ratio [DCR] and fast/slow ratio [FSR]). }\end{array}$ & $\begin{array}{l}\text { The FIFA } 11+\text { programme improved the CSR } \\
\text { and FSR, and thus prevented the possibility of } \\
\text { knee injuries in soccer players. The HarmoKnee } \\
\text { programme showed no improvements. }\end{array}$ \\
\hline $\begin{array}{l}\text { Daneshjoo et } \\
\text { al. (29) }\end{array}$ & $M$ & 36 & $17-19$ & $\begin{array}{l}\text { Players were divided into } 3 \text { groups: FIFA } \\
11+, \text { HarmoKnee and control ( } n=12 \text { in } \\
\text { each group). These exercises were performed } \\
3 \text { times a week for } 2 \text { months ( } 24 \text { sessions). } \\
\text { Proprioception was assessed bilaterally } \\
\text { in } 30^{\circ}, 45^{\circ} \text { and } 60^{\circ} \text { knee flexion using the } \\
\text { Biodex isokinetic dynamometer. Static and } \\
\text { dynamic balance were assessed using } \\
\text { the stork stand test and the Star Excursion } \\
\text { Balance Test (Sebt), respectively. }\end{array}$ & $\begin{array}{l}\text { The static balance with eyes closed } \\
\text { significantly increased in the } 11+\text { by } 12.4 \% \\
\text { and in the HarmoKnee by } 17.6 \% \text { Both } \\
\text { programmes improved proprioception in } 45^{\circ} \\
\text { and } 60^{\circ} \text { knee flexion }(\sim 1 \%) \text {. }\end{array}$ \\
\hline $\begin{array}{l}\text { Kilding et al. } \\
(30)\end{array}$ & M & 24 & $9-12$ & $\begin{array}{l}12 \text { athletes composed the experimental group } \\
\text { and } 12 \text { athletes composed the intervention } \\
\text { group. The experimental group performed } \\
\text { the FIFA } 11+\text { five times a week during } 6 \\
\text { weeks. Before and after the intervention, both } \\
\text { groups performed a battery of soccer-specific } \\
\text { physical tests. }\end{array}$ & $\begin{array}{l}\text { No injuries were observed in both groups } \\
\text { during the study. There was a } 72 \% \text { compliance } \\
\text { with the intervention. Most players found the } \\
\text { FIFA } 11+\text { to be beneficial, but not pleasant } \\
\text { in the prescribed format. There have been } \\
\text { improvements in physical performance and leg } \\
\text { power (3-steps jump and countermovement } \\
\text { jump) increased significantly ( } 3.4 \text { and } \\
6.0 \% \text {, respectively). There was also a } 2 \% \\
\text { improvement in the } 20 \text {-m speed test. }\end{array}$ \\
\hline
\end{tabular}

Note: $\mathrm{G}=$ gender; $\mathrm{N}=$ number of athletes; $\mathrm{ND}=$ no data; $\mathrm{Cl}=$ confidence interval. 
In the study by Soligard et al. (10), 376 injuries were recorded. 215 occurred in the control group and 161 , in the intervention group. The authors found a significant difference between the two groups, a reduced number of knee injuries and reduced risk of injury during matches and training. In another study by Soligard et al. (19), the group who showed higher participation rates in the programme also had a lower risk of injury than the group of athletes with intermediate participation rates. Another important finding is that, among the female athletes whose coaches already knew the programme and implemented it in their teams, the risk of injury was $46 \%$ lower than among those athletes whose coaches had no previous experience with this programme or with any other injury prevention programme. In the study by van Beijsterveldt et al. (24), the results indicate that the incidence of injury and its severity are lower in the group of athletes who performed the FIFA 11+ programme. Moreover, the costs of injury treatment are lower when compared to the control group.

Another study that shows the efficiency of the programme is the one by Junge et al. (23). In this study, after a countrywide campaign to reduce the incidence of soccer injuries in Swiss amateur players, the incidence rate of injuries per thousand hours of training and per thousand hours of match play dropped from 15.2 to 12.5 and from 2.5 to 1.9 , respectively. According to the authors, the program was successfully implemented across the country and proved effective in reducing soccer injuries in amateur athletes, as well as health care costs. Some interesting data from the Swiss National Insurance Company are that, in 2003 about 42,260 injuries were reported and attributed to soccer, resulting in costs of approximately $\$ 130$ million. These findings indicate that a national campaign to implement this warm-up programme is feasible and produces effective results.

Dvorak et al. give other possible explanations for the reduction in the injury rate (12). According to these researchers, the gradual decrease in the number of injuries in sporting events, particularly those with greater media coverage, was due to the fact that strategies aimed at injury prevention received greater attention from the coaching staff and referees became more strict, which increased fair play behaviors (12). For example, this explanation seems to be true, as a lower injury rate was observed in the most recent World Cups when compared to earlier World Cups (during the 2002 FIFA World Cup, the incidence of injuries was 50.7 injuries per 1000 hours of match play, in 2006, this incidence dropped to 45.9 injuries per 1000 hours of match play and in 2010, to 40.1 injuries per 1000 hours of match play).

The only study which did not see a reduction in the injury rate in the group that performed the FIFA $11+$ programme was the one by Steffen et al. (23). According to this group of researchers, this result may be due to the low adherence to warm-up programme showed by the teams in the intervention group. Only 14 of the 58 teams in this group completed more than 20 sessions of the programme during the first three months and each player completed, on average, about 15 training sessions. Thus, the low adherence to the programme was probably responsible for the fact that the programme did not lead to decreased injury rates.

Considering the studies analyzed, we found that, of the 11 studies presented in this review, only 1 was composed of a sample of male athletes. This means that the effectiveness of this type of programme in this specific population is not conclusive and that further studies should be conducted with a focus on the male population group. The other studies with females show more consistent data on the effectiveness of the FIFA 11+ warm-up programme and indicate that this programme is an important measure to prevent injuries due to soccer.

According to the different authors (10, 22, 31), women may be at higher risk of serious injury than men. The rate of cruciate ligaments injuries is three to five times higher among girls than among boys (10), which shows the importance of this kind of attention to the training of women athletes. Arendt et al.(32) says sports injuries are the result from a complex interaction of risk factors. These are classified into two categories: the first is determined by factors associated with the type of sport, the environmental conditions, and the equipments used to practice the sport. The second category comprises individual issues linked to physical and psychosocial aspects, and which can be subdivided into extrinsic (body motion, muscle strength, shoes worn and skill level) and intrinsic issues (joint laxity, member misalignment, dimensions of the intercondylar notch, ligament size and hormonal influence). This would mean that there is more than one single explanation for the increased risk of ligament injuries in women. Thus, the cause of this increased risk would be 
multifactorial, not exhibiting a single predominant feature, be it structural, anatomical or biomechanical.

With regard to age, we found that most studies were conducted with the age group between 13 and 17 years. This implies that a broad range of younger girls and especially boys who play soccer did not made up the samples of these studies. Thus, it is essential that further studies are conducted with samples made up of children younger than 13 years of age, because in this age group training effect and soccer-specific motor skills are still in development. The incidence rates of injuries to different body parts and due to different mechanisms of injury (traumatic or overuse) may lead to an increased understanding of the problem and help implement effective intervention strategies in training and increase prevention awareness.

Lindblom et al. (31) and Steffen et al. (23) criticize the programme proposed by FIFA. They point out that the programme does not provide enough motivational incentive for athletes to repeatedly perform them throughout the season. This would explain the decreasing adherence to the programme. Moreover, the physical stimuli linked to the intensity of the exercises would not be enough to generate improvements in strength and speed. In this sense, the low adherence of coaches and athletes, and the frequency of performance of the programme may explain why the programme showed a non-protective effect on the teams and athletes of the studies. This is an obstacle that must be taken into account by managers and coaches who would like to implement this type of programme with their teams. Thus, the coaching staff and the athletes should become aware of the importance of this type of training to prevent injury. This is a fundamental condition to achieve effective results. We believe that these limitations could be easily overcome with increased awareness of coaches and athletes regarding the benefits of performing the programme. Moreover, some minor modifications could make the programme more attractive, stimulating and appropriate to the fitness level of the teams.

It is important to implement a warm-up programme to prevent injuries in children (in a systematic and organized way) as soon as they begin to play soccer, in order to make it a natural part of their training routines. It is also necessary to boost coaches' understanding of the benefits of injury prevention, both at amateur level and regarding the physical performance level. Coaches should be educated to consider injury prevention a central element in soccer training, because those teams whose coaches know and apply the programme show a reduced number of injuries in their athletes.

In order to standardize results for comparing future studies, it is important that the incidence of lesions is presented according to the number of lesions per 1000 hours of match play or training (12). Another important issue is to use the same definition of sports injury. The consensus established in the first World Congress of Sports Injury Prevention, organized by the F-MARC (14) defines injury as any physical complaint reported by a player due to training or during a soccer match, regardless of the need to get medical attention or stop playing soccer.

Future studies should check the efficiency of current alternatives, such as the use of vibrating platforms and neuromuscular and proprioceptive training, in order to improve coordination, reaction time, motor control and provide adequate rehabilitation. With regard to traumatic injuries, the benefits from the use of stabilizing tape in unstable ankles has been already proved, as well as the enhanced use of safety equipment (shin guard), sporting education for fair play, and punishment of unfair behavior.

\section{Conclusion}

The analyzed studies indicate that the FIFA 11+ warm-up programme for the prevention of sports injuries show positive signs that the use of the programme may help reduce the incidence of injuries in girls aged 13-17 years. In a male children population the results are inconclusive and further research is needed.

Based on the positive results highlighted in this study, we believe that the Brazilian Football Confederation (CBF), the state federations and soccer clubs should be engaged in a campaign to raise coaches awareness about the implementation of training activities aimed at reducing the number of sports injuries. The inclusion of these exercises in daily training activities can be carried out in a relatively simple way and requires little time, and their benefits are of great importance for preserving the physical integrity of soccer players. 


\section{References}

1. Arliani GG, Belangero PS, Runco JL, Cohen M. The Brazilian Football Association (CBF) model for epidemiological studies on professional soccer player injuries. Clinics. 2011;66(10):1707-12.

2. Fédération Internationale de Football Association. FIFA Big Count 2006: 270 million people active in football. 2007 [cited 2012, July 10]. Available from: http://www.fifa.com/mm/document/fifafacts/bcoffsurv/bigcount.statspackage_7024.pdf

3. De Mozzi P, Longo UG, Galanti G, Maffulli N. Bicuspid aortic valve: a literature review and its impact on sport activity. Br Med Bull. 2008;85(2):63-85.

4. Fuller CW, Junge A, DeCelles J, Donald J, Jankelowitz R, Dvorak J. 'Football for Health' - a football-based healthpromotion programme for children in South Africa: a parallel cohort study. Br J Sports Med. 2010;44(8):546-54.

5. Hootman JM, Dick R, Agel J. Epidemiology of collegiate injuries for 15 sports: summary and recommendations for injury prevention initiatives. J Athl Train. 2007;42(2):311-9.

6. Hatami K, Azizbeigi K, Shokrollahi B, Haidari N. The survey of prevalence of sport injuries in student athletes of Islamic Azad University. Middle East J Sci Res. 2011;9(1):123-8.

7. Fong DT, Hong Y, Chan LK, Yung PS, Chan KM. A systematic review on ankle injury and ankle sprain in sports. Sports Med. 2007;37(1):73-94.

8. Junge A, Rösch D, Peterson L, Graf-Baumann T, Dvorak J. Prevention of soccer injuries: a prospective intervention study in youth amateur players. Am J Sports Med. 2002;30(5):652-9.

9. Waldén M, Hägglund M, Ekstrand J. UEFA Champions League study: a prospective study of injuries in professional football during the 2001-2002 season. Br J Sports Med. 2005;39(8):542-6.

10. Soligard T, Myklebust G, Steffen K, Holme I, Silvers H, Bizzini M, et al. Comprehensive warm-up programme to prevent injuries in young female footballers: cluster randomised controlled trial. BMJ. 2008;337:a2469.

11. Baroni BM, Generosi RA, Leal Júnior CE. Incidence and factors related to ankle sprains in athletes of futsal national teams. Fisioter Mov. 2008;21(4):79-88.
12. Dvorak J, Junge A, Derman W, Schwellnus M. Injuries and illnesses of football players during the 2010 FIFA World Cup. Br J Sports Med. 2011;45(8):626-30.

13. Hägglund M, Waldén M, Ekstrand J. Exposure and injury risk in Swedish elite football: a comparison between seasons 1982 and 2001. Scand J Med Sci Sports. 2003;13(6):364-370.

14. Fuller CW, Ekstrand J, Junge A, Andersen TE, Bahr $\mathrm{R}$, Dvorak J, et al. Consensus statement on injury definitions and data collection procedures in studies of football (soccer) injuries. Br J Sports Med. 2006;40(3):193-201.

15. Hägglund $M$, Waldén $M$, Ekstrand J. Injury incidence and distribution in elite football - a prospective study of the Danish and the Swedish top divisions. Scand J Med Sci Sports. 2005;15(1):21-8.

16. Soligard T, Nilstad A, Steffen K, Myklebust G, Holme I, Dvorak J, et al. Compliance with a comprehensive warm-up programme to prevent injuries in youth football. Br J Sports Med. 2010;44(11):787-93.

17. Hagglund M, Walden M, Atroshi I. Preventing knee injuries in adolescent female football players - design of a cluster randomized controlled trial. BMC Musculoskelet Disord. 2009;10:75.

18. Olsen OE, Myklebust G, Engebretsen L, Holme I, Bahr R. Exercises to prevent lower limb injuries in youth sports: cluster randomised controlled trial. BMJ. 2005;330(7489):449.

19. Vescovi JD, VanHeest JL. Effects of an anterior cruciate ligament injury prevention program on performance in adolescent female soccer players. Scand J Med Sci Sports. 2010;20(3):394-402.

20. FIFA's Medical Assessment and Research Centre. The "11+" Manual: A complete warm-up programme to prevent injuries. Zurique: Vogt-Schild/Druck; 2005.

21. Junge A, Lamprecht M, Stamm H, Hasler H, Bizzini M, Tschopp M, et al. Countrywide campaign to prevent soccer injuries in Swiss amateur players. Am J Sports Med. 2011;39(1):57-63.

22. Steffen K, Bakka HM, Myklebust G, Bahr R. Performance aspects of an injury prevention program: a ten-week intervention in adolescent female football players. Scand J Med Sci Sports. 2008;18(5):596-604. 
23. Steffen K, Myklebust G, Olsen OE, Holme I, Bahr R. Preventing injuries in female youth football - a clusterrandomized controlled trial. Scand J Med Sci Sports. 2008;18(5):605-14.

24. Beijsterveldt AM, Krist MR, Schmikli SL, Stubbe JH, de Wit GA, Inklaar $\mathrm{H}$, et al. Effectiveness and costeffectiveness of an injury prevention programme for adult male amateur soccer players: design of a clusterrandomised controlled trial. Inj Prev. 2011;17(1):e2.

25. Gatterer H, Ruedl G, Faulhaber M, Regele M, Burtscher M. Effects of the performance level and the FIFA "11" injury prevention program on the injury rate in Italian male amateur soccer players. J Sports Med Phys Fitness. 2012;52(1):80-84.

26. Grooms DR, Palmer T, Onate JA, Myer GD, Grindstaff T. Soccer-specific warm-up and lower extremity injury rates in collegiate male soccer players. J Athl Train. 2013;48(6):782-9.

27. Steffen K, Emery CA, Romiti M, Kang J, Bizzini M, Dvorak J, et al. High adherence to a neuromuscular injury prevention programme (FIFA 11+) improves functional balance and reduces injury risk in Canadian youth female football players: a cluster randomised trial. Br J Sports Med. 2013;47(12):794-802.

28. Daneshjoo A, Mokhtar AH, Rahnama N, Yusof A. The effects of injury preventive warm-up programs on knee strength ratio in young male professional soccer players. PLoS One. 2012;7(12):e50979.
29. Daneshjoo A, Mokhtar AH, Rahnama N, Yusof A. The effects of comprehensive warm-up programs on proprioception, static and dynamic balance on male soccer players. PLoS One. 2012;7(12):e51568.

30. Kilding AE, Tunstall H, Kuzmic D. Suitability of FIFA's "The 11" Training Programme for Young Football Players - Impact on Physical Performance. J Sports Sci Med. 2008;7(3):320-6.

31. Lindblom $H$, Waldén $M$, Hägglund $M$. No effect on performance tests from a neuromuscular warm-up programme in youth female football: a randomised controlled trial. Knee Surg Sports Traumatol Arthrosc. 2012;20(10):2116-23.

32. Arendt EA, Agel J, Dick R. Anterior cruciate ligament injury patterns among collegiate men and women. J Athl Train. 1999;34(2):86-92.

Received: 08/24/2012

Recebido: 24/08/2012

Approved: 02/27/2015

Aprovado: 27/02/2015 